\title{
MINIMUM RESERVE REQUIREMENTS FOR COMMERCIAL BANKS: THEORY AND PRACTICE
}

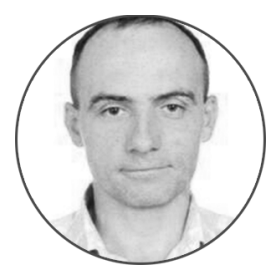

\section{Article history:}

Received 31 July 2017

Received in revised form

3 September 2017

Accepted 10 October 2017

Translated 5 February 2018

Available online 27 March 2018

JEL classification: E58

\author{
Aleksandr N. SUKHAREV \\ Tver State University, Tver, Russian Federation \\ su500005@yandex.ru
}

\begin{abstract}
Importance The article examines the rate of reserve requirements as a monetary policy tool.

Objectives I give a more profound theoretical view of the way reserve requirements for commercial banks influence monetary and credit processes.

Methods I rely upon formal logic, systems approach and analysis of statistical data.

Results I specify the macroeconomic mechanism of minimum reserve requirements. In this respect, I give a walk-through example of changes in reserve requirements and their effects on the quantity of cash and non-cash money as part of the central bank's monetary policy, including inflation targeting. I present my own system of equations for monetary and credit aspects. It helps understand how changes in minimum reserve requirements influence the quantity of both cash and non-cash money in the economy (considering the demand for it).

Conclusions and Relevance Being a monetary policy tool, statutory reserves can be used for microeconomic purposes of the national economy during crises, i.e. supporting the liquidity of the banking system as commercial banks can use them. However, there is a stable correlation between the demand for cash and non-cash money (in the short- and mid-term). Thus, altered minimum reserve requirements induce not only changes in the amount of non-cash money in the economy, but also cash. In this respect, the central bank cannot use the minimum reserve rate as a tool of the monetary policy unless it adjusts the amount of cash money circulating in the economy.
\end{abstract}

(c) Publishing house FINANCE and CREDIT, 2017

The editor-in-charge of this article was Irina M. Vechkanova

Authorized translation by Irina M. Vechkanova

Federal Law On the Central Bank of the Russian Federation of July 10, 2002 № 86-Ф3 (Article 35) pronounces statutory reserves (statutory reserve requirements) to be one of the main tools of the monetary policy. Statutory reserves of commercial banks are primarily designated to regulate money circulation, that is total money supply, thus controlling the inflation rate [1-3]. Central banks manage the money supply in circulation not only by changing

${ }^{\dagger}$ For the source article, please refer to: Сухарев А.Н. Норма обязательных резервов для коммерческих банков: теория и практика. Финансы и кредит. 2017. Т. 23. № 41. С. 2456-2467. URL: https://doi.org/10.24891/fc.23.41.2456 the amount of cash money, but also altering reserve requirements. They assume that an increase in reserve requirements shall reduce the money supply in the economy, and vice versa $[4,5]$. Reserve requirements are normally regarded as one of the most important tools of the monetary policy [6-8]. However, it is still a point of controversy whether this economic lever is effective [9-11]. In my opinion, a more complex mechanism exists to manage the money supply in the economy, than the one which is usually described in macroeconomic textbooks and used by central banks in making decisions on monetary regulation issues. 
Assume a classic example of the effect statutory reserves have on the money supply in the economy.

For example, the central bank injects 100 billion money units (MU) into circulation and sets up reserve requirements of 20 percent. Economic agents open accounts for 200 billion MU at banks, while the banks retain 20 percent of money in those accounts (40 billion $\mathrm{MU}$ ) and deposit it at the central bank as statutory reserves withdrawn from circulation. As a result, 260 billion $\mathrm{MU}$ of cash and non-cash money totally remains in the economy, including 200 billion MU of non-cash and 60 billion MU of cash money. Economic agents may use cash and money at bank accounts for payments. It is noteworthy that entities primarily settle their accounts by wiring money. Therefore, the amount of non-cash money is another driver of inflation as well as cash.

When reserve requirements are lowered from 20 to 12.5 percent, statutory reserves decrease down to 25 billion MU (200 billion MU · 12.5\%/100\%), and cash money increases by 15 billion MU. Hence total money supply in the economy will account for 275 billion MU.

As seen from the above example, changes in reserve requirements modify only the amount of cash money in the economy, without influencing non-cash money. It also alters the ratio of cash and non-cash money, thus correspondingly increasing the percentage of non-cash money in the total money supply in the economy. Such consequences are assumed to occur only in the short-term period, while the mid- and long-term periods see the ratio of cash and non-cash money recovering (in full or partially).

It is important to determine which type of money (cash or non-cash) influence the inflation rate and to what extent it does so. Three components of non-cash money shall be pointed out:

- money available on plastic cards (e-money) (m1);

- money in settlements accounts (m3);

- money in deposit accounts (m2).

Components $m 1$ and $m 2$ represent money that serves as a medium of exchange, being involved in circulation. Component $m 3$ stands for money that serves as a medium of savings. The amount of $m 1$ and $m 2$ directly influences the level of prices, while $m 3$ can do so only indirectly, when it morphs into $m 1$ or $m 2$.

As for the above components, the equation of exchange can be expressed in the following extensive form:

$$
\begin{aligned}
& m 0 \cdot V 0+m 1 \cdot V 1+m 2 \cdot V 2= \\
& =p 1 \cdot q 1+p 2 \cdot q 2+\ldots+p n \cdot q n,
\end{aligned}
$$

where $m 0$ denotes the amount of cash money;

$V_{0}, V_{1}$ and $V 2$ mean the time it takes for various components of money (cash, electronic and held in accounts) to circulate when they are used for purchase of goods, payment for services and work (the number of their turnover for a certain period of time);

$p 1, p 2, \ldots, p n$ represent prices for various goods out of $n$;

$q 1, q 2, \ldots, q n$ stand for the number of goods (work, services) purchased for a certain period of time.

It should be noted that each of the money components $(m 0, m 1$ and $m 2)$ in circulation is usually involved at different levels of commodity exchange relationships. Correspondingly, each money component directly influences the level of prices in their area of circulation. Whereas money circulates among those levels, it balances and coordinates prices determined by components $m 0, m 1$ and $m 2$.

If cash money accounts for a higher percentage of total money supply intended for transactions, as a result of a decrease in statutory reserve requirements, it will meddle in the ordinary payment procedure in the economy and redistribute percentages of cash and non-cash money [12]. Under the ordinary payment procedure, the public uses a generally accepted nature of payments in the economy at the given moment. This is due to the fact that people use plastic cards with a different frequency and have their own payment preferences. Entities primarily make principal payments by wire transfers across settlement accounts. This determines the amount of cash and cashless payments in the economy, thus influencing the respective balances. To say it in other words, there is an equilibrium ratio of cash and non-cash money in the economy. 
If formalized, it can be expressed as follows: $\frac{M_{\text {cash }}}{M_{c}}=$ constant ,

where $M_{\text {cash }}$ is the amount of cash money;

$M_{c}$ is the amount of non-cash money for settlements and payments in the economy.

This constant is relevant to a short period of time, changing in a long-term one due to structural shifts in the system of monetary payments.

The proper ratio of cash and non-cash money will recover as cash money morphs into non-cash one. However, such transformation does not imply the exchange of 1 cash RUB in for 1 non-cash RUB, but relies upon a monetary multiplier - 1 cash RUB for $n$ non-cash RUB. In this example, the monetary multiplier equals 8 (1/0.125), i.e. 1 cash RUB converts into 8 non-cash RUB until the previous ratio of cash and non-cash money recovers. Assume that in this example 60 billion MU of 200 billion non-cash MU serve for circulation purposes (money for transactions), while the remaining 140 billion $\mathrm{MU}$ are held in deposit accounts, i.e. being used for savings only. Therefore, there were 120 billion $\mathrm{MU}$ for transactions in the economy ( 60 billion $\mathrm{MU}$ in a cash and non-cash form). Cash money accounted for 50 percent of total money supply in circulation or 1 cash RUB is equivalent to 1 non-cash RUB for settlements and payments. To recover the former ratio, 1 RUB in circulation shall be remitted to statutory reserves to create 8 non-cash RUB.

To assess the amount of cash and non-cash money for transactions given the former ratio of cash and non-cash money recovers, the following system of equations shall be solved:

$$
\begin{aligned}
& M=M_{\text {cash }}+M_{n c a s h} ; \\
& M_{c a s h}=M B-R R ; \\
& M_{n c a s h}=R R \mid N R ; \\
& M_{n c a s h}=M_{c}+M_{s} ; \\
& M B=M_{\text {cash }}+R R ; \\
& \frac{M_{c a s h}}{M_{c}}=\text { constant }
\end{aligned}
$$

where $M$ is the amount of cash and non-cash money in the economy;
$M_{\text {cash }}$ is the amount of cash money;

$M_{\text {ncash }}$ is the amount of non-cash money;

$M B$ is the amount of monetary base (in the strict sense);

$R R$ is the amount of statutory reserves;

$N R$ is reserve requirements (ratio);

$M_{c}$ is the amount of non-cash money in circulation (non-cash money for transactions);

$M_{s}$ is the amount of non-cash money for savings.

The first equation shows that total money supply in the economy equals the amount of cash and non-cash money. The second equation indicates that the amount of cash money is the same as the amount of monetary base less statutory reserves. The third equation allows us to assess the amount of non-cash money by multiplying statutory reserves. The forth equation means that the quantity of non-cash money is the non-cash amount in circulation (in settlement accounts and on plastic cards) and cash money intended for saving purposes (bank deposits). The fifth equation is reflective of the fact that the money base (in the strict sense) is the sum of cash money and statutory reserves. The sixth equation indicates that there is a certain correlation between the demand for cash and non-cash money used for transactions (in circulation).

Inserting the numbers into the equation, the result is as follows:

$$
\begin{aligned}
& M=M_{\text {cash }}+M_{n c a s h} ; \\
& M_{\text {cash }}=100 \text { billion } \mathrm{MU}-R R \\
& M_{n c a s h}=R R \mid 0,125 ; \\
& M_{n c a s h}=M_{c}+140 \text { billion } \mathrm{MU} ; \\
& M B=M_{c a s h}+R R ; \\
& \frac{M_{c a s h}}{M_{c}}=2 .
\end{aligned}
$$

Solving the system of equation, I roughly get that $M_{\text {cash }}=73.3$ billion $\mathrm{MU}, M_{c}=73.3$ billion $\mathrm{MU}$. Thus, the ratio of cash and non-cash money used for payments recovers up to the previous one $(1: 1)$. It requires to reduce the amount of cash money by 1.7 billion $\mathrm{MU}$ by remitting it to statutory reserves and increasing non-cash money by 13.3 billion MU, including the multiplier effect. Hence total money supply in the economy will rise by 11.6 billion MU (13.3 billion MU - 
1.7 billion $\mathrm{MU}$ ) up to 286.6 billion MU (cash money 73.3 billion $\mathrm{MU}$; non-cash money in circulation 73.3 billion MU; 140 billion MU - non-cash money for saving purposes).

Total money supply in circulation will grow by 22 percent, from 120 billion MU (20-percent reserve requirements) up to 146.6 billion $\mathrm{MU}$ (12.5-percent reserve requirements). Assuming an equal and unchanged money velocity for cash and cashless payments, it will induce a price growth by 22 percent. If decreased reserve requirements did not recover the former ratio of cash and non-cash money in circulation, prices would have grown slower, reaching 12.5 percent, provided that money in circulation increased from 120 to 135 billion MU.

It is worth mentioning that the amount of money in deposit accounts proves to be almost inert in relation to changing reserve requirements in a short and mid run. There are no explicit mechanisms for altering them after reserve requirements change. $M_{s}$ reflects the income saved in the past. In a long-term period growing prices (in the given case a growth stemming from decreased reserve requirements) unleash a nominal growth in income, thus increasing $M_{s}$. Considering that the money base remains stable, this will instigate the demand for non-cash money $M_{s}$ and reduce cash money in circulation since they will be remitted to reserve requirements, being an indispensable measure for raising $M_{s}$. Concurrently the amount of non-cash money in circulation $\left(M_{c}\right)$ would shrink. Assuming that the ratio of the three money base components $\left(M_{\text {cash, }} M_{c}\right.$ and $\left.M_{s}\right)$ would become as it was before reserve requirements had been lowered down to 12.5 percent (60:60:140 respectively), $M_{\text {cash }}, M_{c}$ and $M_{s}$ will account for 70.6 billion $\mathrm{MU}, 70.6$ billion $\mathrm{MU}$ and 164.7 billion $\mathrm{MU}$ respectively provided the money base of RUB 100 billion remains unchanged. Total cash and non-cash money in the economy will amount to 305.9 billion $\mathrm{MU}$, and money in circulation will account for 141.2 billion MU. This will reduce its amount down to 5.4 billion $\mathrm{MU}$ to an extent (141.2 billion MU 146.6 billion $\mathrm{MU}=-5.4$ billion $\mathrm{MU})$. Ceteris paribus, it will induce a decrease in the general level of prices by 4.5 percent (against the level prevailing before a reduction in reserve requirements).

As a matter of fact, the money base is fluctuating. Central banks generally extend it. Thus, the above processes shall be regarded as ideal conditions. However, they help comprehend complex monetary and credit processes in the economy by decomposing them into separate factors and steps.

In the early 1990s, Russia had a 20-percent cap on reserve requirements, but even such measures were not enough to target inflation successfully and keep it low. The Central Bank of Russia set up the inflation target as much as 4 percent per annum in 2017.

Table 1 quantifies the money base (in the strict sense) throughout 2002-2017.

As of January 1, 2017, statutory reserves accounted for 3.2 percent of the money base (in the strict sense). During the 2008-2009 financial crisis, the Central Bank of Russia had to support the banking system by permitting commercial banks to use statutory reserves so that they could increase their liquidity and solvency. Such measures are unparalleled since statutory reserves were used as a tool for monetary regulation to tackle microeconomic issues, thus contravening their purpose [13]. Based on theoretical views of the substance and mechanism of statutory reserves, such measures should have resulted in a substantial multiplication of non-cash money and inflation growth $[14,15]$. In fact, nothing of the kind happened. The reason may be that the demand for non-cash money has its own distinctions during the crisis in the Russian economy and the decline in statutory reserves did not last for a long period of time. For example, as of January 1, 2008 statutory reserves accounted for RUB 150.5 billion with the money base (in the strict sense) of RUB 4.3 billion. However, in a year, as of January 1, 2009, it amounted to RUB 19.6 billion with the money base (in the strict sense) of RUB 4.4 trillion. As of May 1, 2017 cash issued by the Central Bank of Russia into circulation accounted for RUB 8,630.5 billion, with the statutory reserves amounting to RUB 306.1 billion. Therefore, statutory reserves account for 3.4 percent of the money base (in the strict sense).

As shown in Table 1, the percentage of statutory reserves in the money base varied within 2002-2007 in Russia. Those changes were divisible (the ratio of the highest and lowest percentages was $13.1 \% / 0.4 \%=$ 32.75 times). In the mean time, such fluctuations of statutory reserves did not cause the same effect in 
the money base (in the strict sense). The share of statutory reserves diminished in the money base (in the strict sense) from 3.5 (2008) to 0.4 percent (2009) concurrently with slight changes in the money base increment (in the strict sense) driven by a growth in the quantity of non-cash money, rather than its volume. Identical inconsistencies of theory and practice occur in other comparable periods too. This may be due to the fact that theoretical views of the monetary multiplier shall be further studied.

The central bank does not accrue interests on funds commercial banks deposit. The central bank withdraws those funds from circulation, without gaining any yields and being bound to pay interests respectively. In fact, the central bank does derive income from the funds.

The following simple example illustrates this statement. Assume the central bank released 100 billion MU in cash for circulation purposes. The central bank effectuates such issues by purchasing income-bearing financial assets. Therefore, the central bank acquires the title for the income-bearing financial assets for 100 billion $\mathrm{MU}$ as well. Accepting 20 billion MU from commercial banks to make statutory reserves and withdraw them from circulation, the central bank retains the same financial assets even if the total amount of cash money in circulation diminishes. From perspectives of the balance sheet, it will have the following presentation. Take the central bank's assets for 100 billion MU of income-bearing financial assets. The central bank's liabilities are the amount of cash money in circulation ( 80 billion $\mathrm{MU}$ ) and statutory reserves (20 billion $\mathrm{MU})$.

The Central Bank of Russia assesses the money base indicators in the strict and broad sense. The money base in the strict sense shall mean an amount of cash money issued by the Central Bank into circulation, and statutory reserves credit institutions deposit at the Central Bank of Russia. The money base in the broad sense constitutes the money base in the strict sense, money deposited with the Central Bank by the enlarged government, commercial banks' funds deposited with the Central Bank and bonds issued by the Central Bank. What the money base signifies economically in its strict sense is that this money aggregate directly influences national trends in prices. As for the money base in the broad sense, it represents the highest amount of cash money, which may circulate under the current obligations of the Central Bank of Russia [16, 17].

Central banks refuse to pay interests on statutory reserves due to the tradition tracing back to times when central banks assumed issuing functions. They are still reluctant to part with income they earn. Being non-profit organizations free from profit-making ambitions, central banks pursue profit of political significance mostly [18]. Profit motivates central banks less than losses they may have igniting possible severe criticism about their management. Such circumstances may inflict managerial rearrangements and staff's salary cuts. The public considers the central bank's profit as a testimony to the effective financial management.

Whereas interests are not paid on statutory reserves deposited with the central bank, commercial banks have to set an increased interest margin. Commercial banks shall transfer some of the funds and deposits they attract to the central bank. So, the funds and deposits will not generate income for commercial banks. Therefore, they need to ensure higher yields from funds they have available. Therefore, the higher reserve requirements, the higher interest margin of commercial banks shall be. Interest rates on loans grow correspondingly with reserve requirements. As I conclude, as a tool of the monetary policy, statutory reserves can be utilized for microeconomic purposes at the national level during crises so as to maintain liquidity of the banking system by allowing commercial banks to rely on those reserves. Reserve requirements are intended to regulate the volume of non-cash money in the economy.

However, changes in reserve requirements inflict the same in the volume of both cash and non-cash money since there is some sustainable correlation between the demand for cash and non-cash money (in the short- and mid-term period). In this case, the central bank cannot make use of reserve requirements as a tool of the monetary policy unless it adjusts the volume of cash money in the economy. 


\section{Table 1}

The monetary base (in the strict sense) and its structure, 2002-2017

\begin{tabular}{lllll}
\hline As of January 1 & $\begin{array}{l}\text { Monetary base } \\
\text { in the strict sense }\end{array}$ & Cash in circulation & $\begin{array}{l}\text { Statutory reserves denominated } \\
\text { in national currency }\end{array}$ & $\begin{array}{l}\text { Percentage of statutory reserves } \\
\text { in the monetary base in the strict sense }\end{array}$ \\
\hline 2002 & 717.2 & 623.5 & 93.7 & 13.1 \\
\hline 2003 & 935.1 & 813.9 & 121.2 & 13 \\
\hline 2004 & $1,398.5$ & $1,224.7$ & 173.8 & 12.4 \\
\hline 2005 & $1,746.2$ & $1,669.9$ & 76.3 & 4.4 \\
\hline 2006 & $2,298.9$ & $2,195.4$ & 103.5 & 4.5 \\
\hline 2007 & $3,208.3$ & $3,062.1$ & 146.2 & 4.6 \\
\hline 2008 & $4,269.1$ & $4,118.6$ & 150.5 & 3.5 \\
\hline 2009 & $4,391.7$ & $4,372.1$ & 19.6 & 0.4 \\
\hline 2010 & $4,715.9$ & $4,622.9$ & 93 & 2 \\
\hline 2011 & $5,912.8$ & $5,785.2$ & 127.6 & 2.2 \\
\hline 2013 & $7,149.5$ & $6,895.8$ & 253.7 & 3.5 \\
\hline 2014 & $7,959.7$ & $7,667.7$ & 292 & 3.7 \\
\hline 2015 & $8,598.2$ & $8,307.5$ & 290.7 & 3.4 \\
\hline 2016 & $9,139.8$ & $8,840.5$ & 299.3 & 3.3 \\
\hline 2017 & $8,745.9$ & $8,522.2$ & 223.7 & 2.6 \\
\hline
\end{tabular}

Source:Authoring, based on the Central Bank of Russia website data. URL: http://www.cbr.ru 


\section{References}

1. Pronchatov E.A. [Reserve requirements of the Bank of Russia in the service of social and economic policy of the State]. Bankovskoe delo = Banking, 2011, no. 7, pp. 21-24. (In Russ.)

2. Frolova E.E., Karmadonova E.V. [Reserve requirements as an instrument of monetary policy]. Grazhdanin $i$ pravo, 2014, no. 1, pp. 28-35. (In Russ.)

3. Pashkovskaya I.V. [Philosophers' stone of bank system]. Bankovskie uslugi = Banking Services, 2014, no. 3, pp. 8-12. (In Russ.)

4. Kovtun Z.O. Developments in Money Multiplier after the Crisis. European Social Science Journal, 2014, no. 3-1, pp. 415-425. (In Russ.)

5. Uryupina A.A. [The banking sector in terms of a restraining monetary policy]. Bankovskie uslugi = Banking Services, 2008, no. 7, pp. 2-4. (In Russ.)

6. Berdyshev A.V. [Essence of required reserves and practice of their usage in Russia]. Audit i finansovyi analiz = Audit and Financial Analysis, 2008, no. 1, pp. 13-18.

URL: http://www.auditfin.com/fin/2008/1/Berdishev/Berdishev\%20.pdf (In Russ.)

7. Goidenko Yu.N. [Notes to the discussions of the money multiplier]. Ekonomika i predprinimatel'stvo = Journal of Economy and Entrepreneurship, 2012, no. 3, pp. 65-68. (In Russ.)

8. Igumnov O.A., Lyu Sh. [Monetary policy of the State: essence and tools]. Ekonomika i sotsium, 2015, no. 2-2, pp. 676-679. (In Russ.)

URL: http://iupr.ru/domains_data/files/sborniki_jurnal/Zhurnal\%20_2(15)\%202.pdf

9. Phung The Dong. [Evaluating the effectiveness of reserve requirements in monetary policy of Vietnam]. Internet-zhurnal Naukovedenie, 2014, no. 1, pp. 82-83. (In Russ.)

URL: https://naukovedenie.ru/PDF/10TVN114.pdf

10. Kuz'mina V.S., Kuz'mina O.Yu. [Effectiveness of tools of monetary policy of the Central Bank of the Russian Federation in the context of their influence on real production sector]. Ekonomika i sotsium, 2016, no. 8, pp. 240-247. (In Russ.) URL: http://iupr.ru/domains_data/files/zurnal_27/Kuzmina\%20V.S.,.pdf

11. Stepanova A.M. [Features of development of the domestic mechanism of monetary regulation]. Бізнес інформ, 2015, no. 9, pp. 325-330. (In Russ.)

URL: http://www.business-inform.net/export_pdf/business-inform-2015-9_0-pages-325_330.pdf

12. Harris L. Denezhnaya teoriya [Monetary Theory]. Moscow, Progress Publ., 1990, 750 p.

13. Novashina T.P., Karpunin V.I., Volnin V.A. [Mechanisms of functioning reserve requirements in a context of maintenance financial stability of banks]. Ekonomicheskie nauki = Economic Sciences, 2008, no. 40, pp. $319-331$. (In Russ.)

14. Andryushin P.A., Burlachkov V.K. [The mechanism of the monetary multiplier: the world and Russian practice]. Bankovskoe delo = Banking, 2015, no. 12, pp. 4-11. (In Russ.)

15. Yurkova G.V., Zalunina L.V. [A look at surplus liquidity in the banking sector]. Den'gi $\mathrm{k}$ kredit $=$ Money and Credit, 2013, no. 4, pp. 47-59. (In Russ.)

16. Burlachkov V. [Money supply: theory and organization]. Voprosy Ekonomiki, 2005, no. 3, pp. 48-60. (In Russ.) 
17. Kosukhin P.P. [Currency issue in bank system]. Nauchnye trudy Vol'nogo ekonomicheskogo obshchestva Rossii = Transactions of the Free Economic Society of Russia, 2010, no. 136, pp. 277-283. (In Russ.)

18. Stella P. Do Central Banks Need Capital? IMF Working Paper, 1997, no. 97/83, 39 p.

URL: http://www.imf.org/en/Publications/WP/Issues/2016/12/30/Do-Central-Banks-Need-Capital-2260

\section{Conflict-of-interest notification}

I, the author of this article, bindingly and explicitly declare of the partial and total lack of actual or potential conflict of interest with any other third party whatsoever, which may arise as a result of the publication of this article. This statement relates to the study, data collection and interpretation, writing and preparation of the article, and the decision to submit the manuscript for publication. 